Article

\title{
Lithological Identification and Underground Water Conditions in Jeddo Using Geophysical and Geochemical Methods
}

\author{
Ruth Iserhien-Emekeme ${ }^{1, *}$, Merrious Oviri Ofomola ${ }^{1}$ (D), Musa Bawallah ${ }^{2}$ and \\ Ochuko Anomohanran 1 \\ 1 Department of Physics, Delta State University, 330106 Abraka, Nigeria; ovirimerrious@yahoo.com (M.O.O.); \\ mrochuko@yahoo.com (O.A.) \\ 2 Department of Applied Geophysics, Federal University of Technology, 340252 Akure, Nigeria; \\ musabawallah@gmail.com \\ * Correspondence: ruth.emekeme1@gmail.com
}

Received: 18 July 2017; Accepted: 16 August 2017; Published: 21 August 2017

\begin{abstract}
Resistivity soundings and hydrogeochemical methods were carried out in order to establish the characteristics of the aquifer in Jeddo, Southern Nigeria. Results of the resistivity sounding revealed that the formation is made up of clay, clayey sand, and fine- to coarse-grained sand. The mean depth of the aquifer was obtained as $12.7 \mathrm{~m}$ while the aquifer resistivity ranged from 161 to $1728 \Omega \mathrm{m}$. The mean value of transmissivity obtained for the aquifer is $169 \mathrm{~m}^{2}$ day $^{-1}$ while analysis of the transmissivity revealed that about $6 \%$ of the study area has greatest potential for a productive aquifer. The study also revealed that the underground water flows in the northeast-southwest direction. The hydro geochemical analysis of water samples showed that some parameters such as lead, color and $\mathrm{pH}$ exceeded the permissible limits, which were established by Federal Environmental Protection Agency and the World Health Organization. It is concluded from the water quality index (WQI) that the groundwater is of poor quality and requires some remediation before it can be used for domestic and industrial purposes.
\end{abstract}

Keywords: electrical resistivity; aquifer transmissivity; aquifer protective capacity; groundwater flow; water quality index

\section{Introduction}

Jeddo, the study area, is in the western part of the Niger Delta region of Delta State, Nigeria. It has altitude of about $23 \mathrm{~m}$, an elevation of about 3-12 $\mathrm{m}$ above sea level and it is about $437 \mathrm{~km}$ south-west of the country's capital city, Abuja. It lies between latitude $5.583^{\circ} \mathrm{N}$ and $5.600^{\circ} \mathrm{N}$ and longitude $5.710^{\circ} \mathrm{E}$ and $5.716^{\circ} \mathrm{E}$ (Figure 1). The area is characterized by tropical equatorial climate with a mean annual temperature of $32.8^{\circ} \mathrm{C}$ and an annual rainfall of $2673.8 \mathrm{~mm}$ [1]. It is an established fact that the annual temperature and amount of rainfall is highly variable from year to year [2]. The region has witness an influx of people in recent times due to its proximity to the Warri Refinery and Petrochemical Company (WRPC), resulting in an ever-rising demand for water. Municipal water supply is not available in the community, thus several water wells have been drilled by individuals without preliminary geophysical, geological, and hydrogeological investigation, in search of potable drinking water.

The lithological identification of the subsurface and underground water characteristics of an area can be effectively determined by drilling of several boreholes and interpretation of the soil and water samples collected. This is both cost- and labor-intensive. Today however, great emphasis is placed on planned exploration and utilization of water resources which is a non-invasive, relatively cheap and quantitative technique. This exploration requires the use of various geophysical, hydrogeological and 
geochemical methods such as seismic, electromagnetic, magnetic, ground probing radar, and electrical resistivity methods among others.

The surface electrical resistivity method uses various techniques and instruments in its investigation and is useful in determining the thickness and resistivity distribution of the subsurface [3]. The technique measures the properties of an earth material, which are related to hydraulic parameters. The success of the method is due to the variation of conductivity within the earth's subsurface layers, which in turn affects the distribution of electric potential. The degree of this effect depends on the shape, size, location and bulk electrical resistivity of the subsurface layers. The bulk electrical resistivity depends on the mineralogy of the rocks and its contained fluids [4].

The use of electrical methods applied to environmental studies is well documented by many geophysicists [5-16]. This paper provides a geoelectrical (resistivity) method for parameter estimation as complimentary /alternative approach to direct methods and is aimed at estimating the lithology, resistivity, longitudinal conductance and transverse resistance, hydraulic conductivity, transmissivity, direction of underground water flow, and protective capacity of the aquifer in Jeddo, located within the Niger Delta basin. It also includes results of water analysis carried out to ascertain the geochemical composition of the underground water.

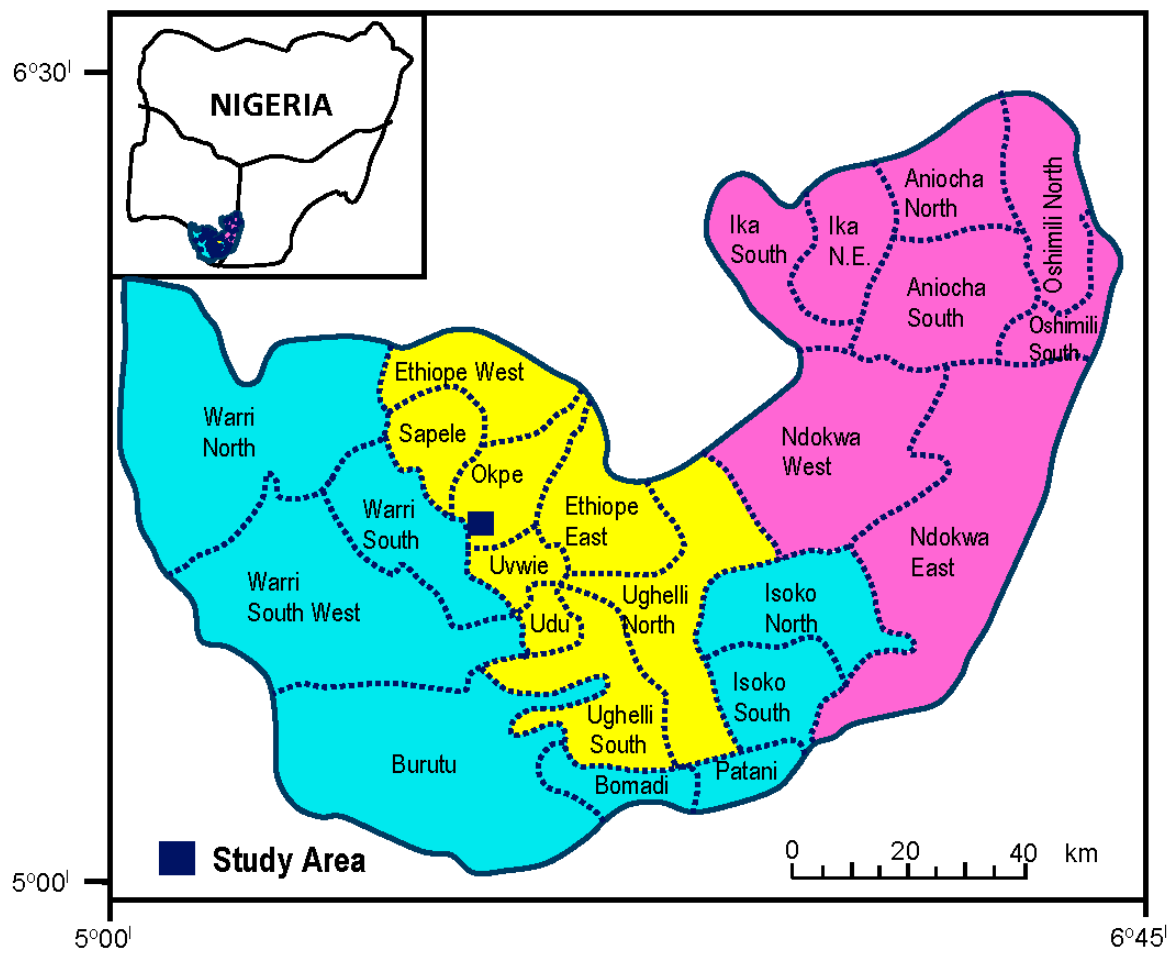

Figure 1. Map of Delta State showing the study area.

\section{Geology of Study Area}

The subsurface geology of the Niger Delta Basin to which Jeddo belongs is well established [17-20]. The basin fill is made up of three formations, namely the Benin, Agbada and Akata Formations, from the youngest to oldest. The continental Miocene-Recent Benin Formation conformably overlies the Agbada Formation. Its lithologic composition is $90 \%$ sand and about $10 \%$ clay and lignite bed [17]. The sands range in size from gravelly, coarse- to fine-grained. They are also poorly-sorted, sub-angular to well-rounded, and bear lignite streaks and wood fragments. Its porosity, which decreases with depth, ranges from 15 to $31 \%$ in the basin [21]. It has numerous prolific aquifers. The Agbada Formation conformably overlies the Akata Formation in the subsurface. It is a parallic sequence of alternating shale and sandstone with a variable age ranging from Eocene to Pliocene/Pleistocene and Recent in the 
Delta surface. The Akata Formation, also known as marine shale ranges from Paleocene to Holocene in age and is composed of shale, silts, clay and turbidity sand at the base of the Delta sequence. The shale is believed to be over pressured and highly compacted [18].

\section{Methodology}

Many investigative techniques are commonly employed in estimating the spatial distribution of aquifer parameters [5-16]. In this research work, the Allied Ohmega Terrameter was used to obtain seventeen vertical electrical soundings (VES) in order to establish the characteristics of the aquifers in the study area. The VES locations are as shown in Figure 2.Interpretation of VES results was done using the RESIST software, which is an iterative inversion-modeling program. Analysis of the resulting apparent resistivity versus the half-current electrode separations were used to obtain the earth models composed of individual layers of specified thickness (h) and apparent resistivity $(\rho)$ from which the longitudinal conductance $\left(\mathrm{S}_{\mathrm{L}}=\mathrm{h} / \rho\right.$ unit $\left.\Omega^{-1}\right)$, transverse resistance $\left(\mathrm{R}=\mathrm{h} \rho\right.$ unit $\left.\Omega \mathrm{m}^{2}\right)$ and transmissivity $\left(\mathrm{T}=\mathrm{Kh}\right.$, unit $\left.\mathrm{m}^{2} / \mathrm{s}\right)$ were calculated.

Several groundwater surface maps contoured using Surfer 8 software were used for analysis. Hydrogeochemical analysis was also carried out on water samples collected from existing hand dug wells and boreholes in the study area to predict the quality of the underground water. The water samples are Grab samples collected from various hand dug wells and boreholes using new one-liter bottle and analyzed in the Analytical Laboratory of the Department of Chemistry, Delta State University, Abraka, Nigeria.

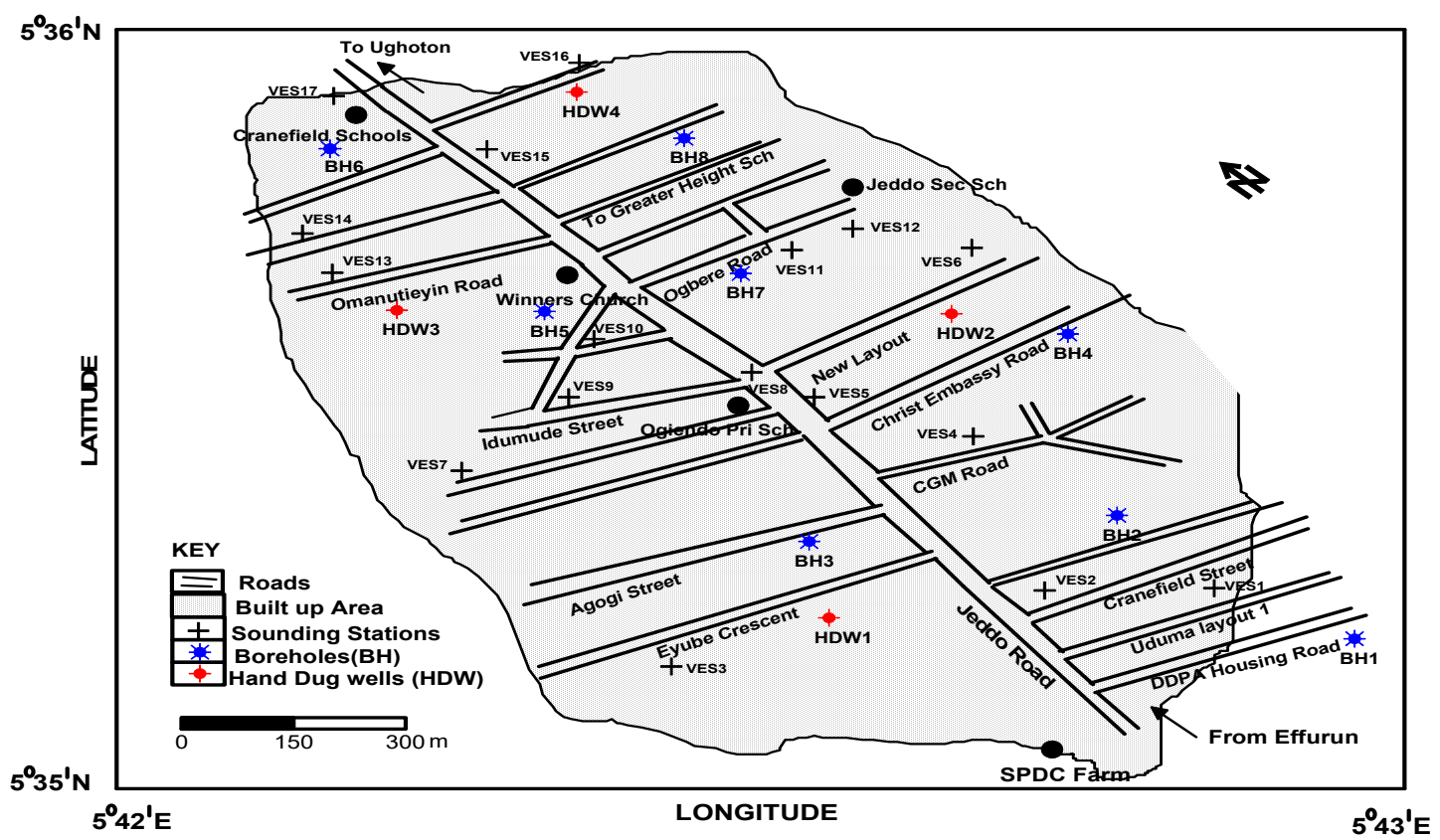

Figure 2. Map of the study area showing the positions of boreholes and vertical electrical soundings.

\section{Results and Data Analysis}

\subsection{Geoelectric Model}

To reveal the geologic sections in various parts of the study area, geoelectric sections based on the interpretation of VES results (Table 1) were generated as shown in Figures 3-5. The depth to water table was determined (ranging from $1.5 \mathrm{~m}$ to $35 \mathrm{~m}$ with an average aquifer depth of $12.7 \mathrm{~m}$ ) and two sediments (unsaturated and saturated) identified. The unsaturated sediments consist of topsoil with resistivity values varying from 21 to $226 \Omega \mathrm{m}$. The location studied shows a sequence of saturated sediment consisting of clay layers $(16 \leq \rho \leq 92 \Omega \mathrm{m})$ for VES $2,3,4,5,10$ and 12 , while clayey sand 
layers (95 $\leq \rho \leq 113 \Omega \mathrm{m}$ ) were identified for VES 5, 9, 10 and 16. Fine- to medium-grained sand $(113 \leq \rho \leq 1728 \Omega \mathrm{m})$, indicating the presence of productive aquifers in the area, was also identified in all VES. Coarse sand encountered in VES 6 has a resistivity of $4205 \Omega \mathrm{m}$.

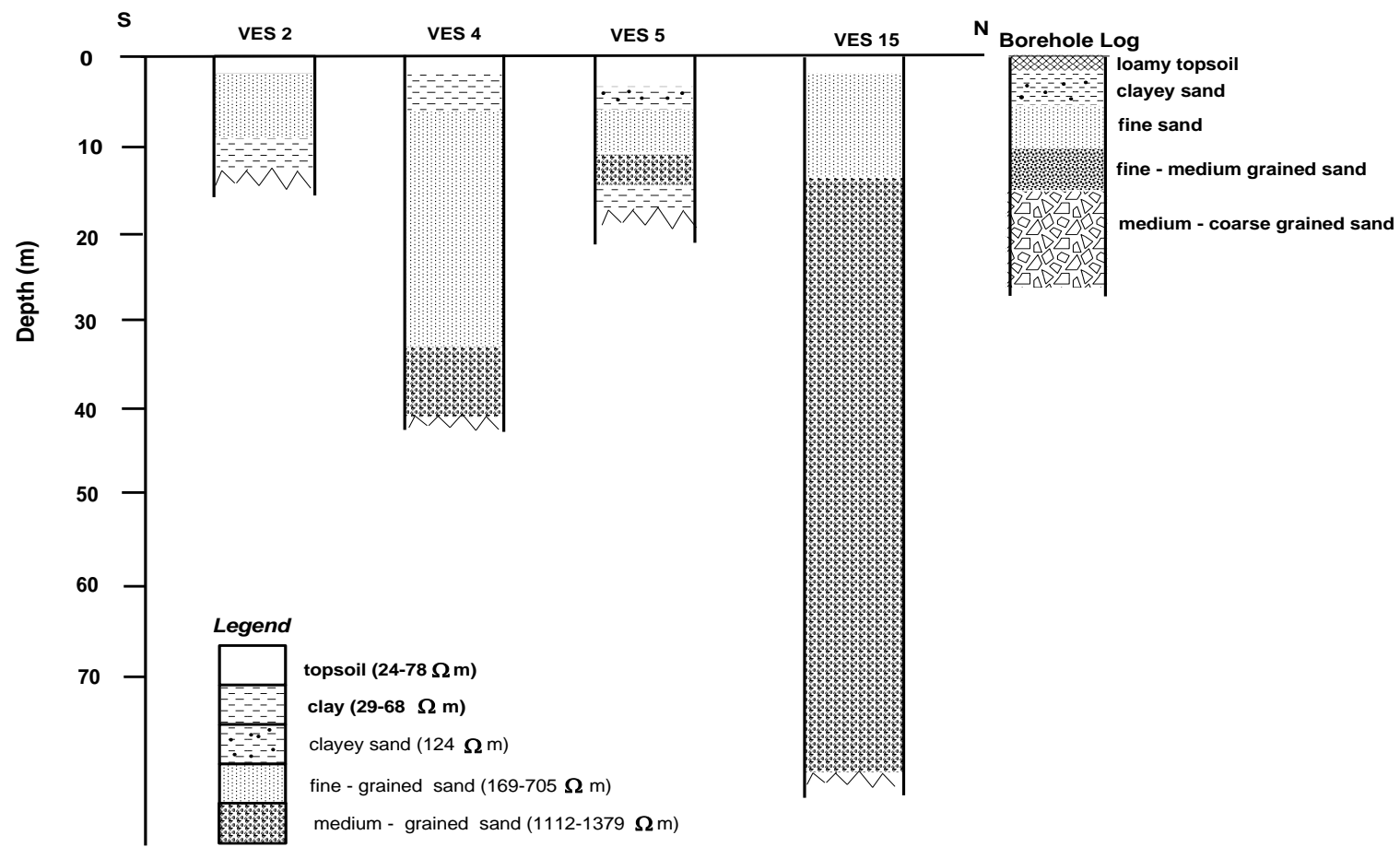

Figure 3. Geoelectric section showing vertical electrical soundings (VES) points along the direction north-south.

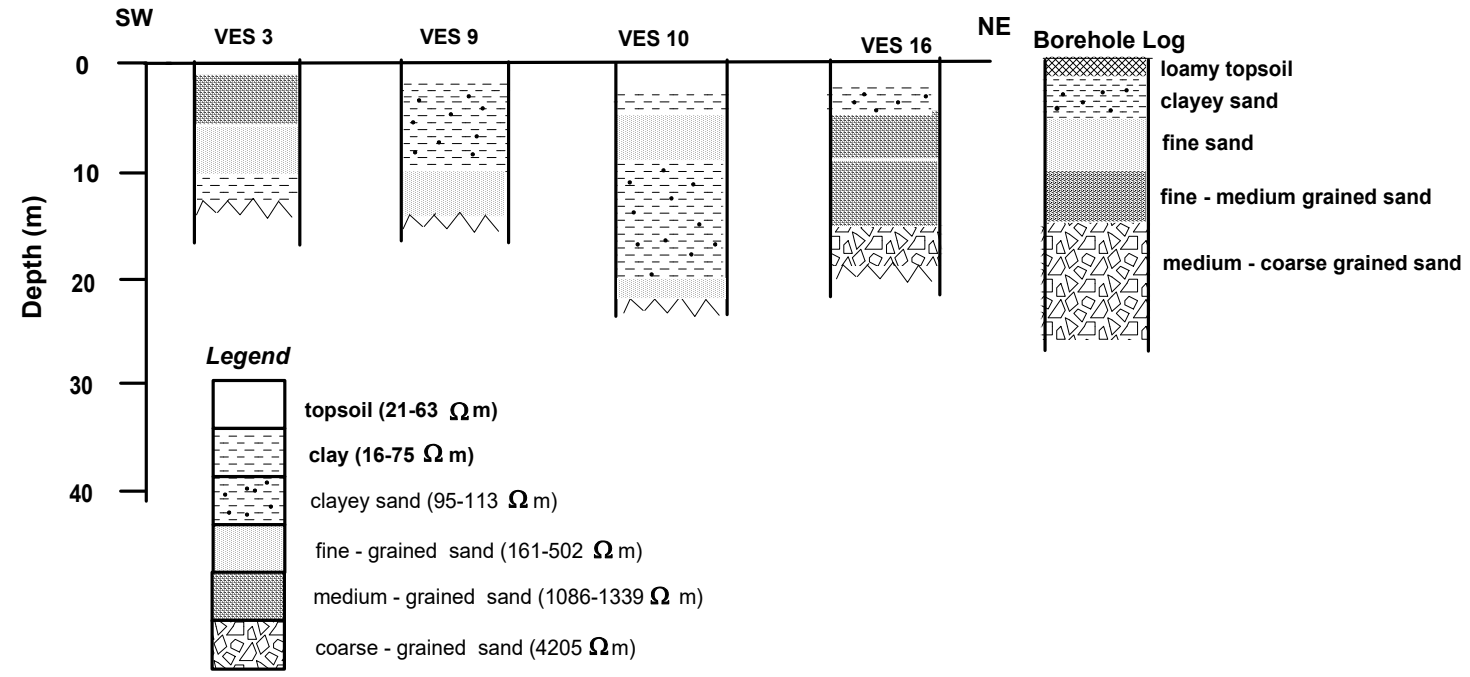

Figure 4. Geoelectric section showing VES points along the direction southwest-northeast. 


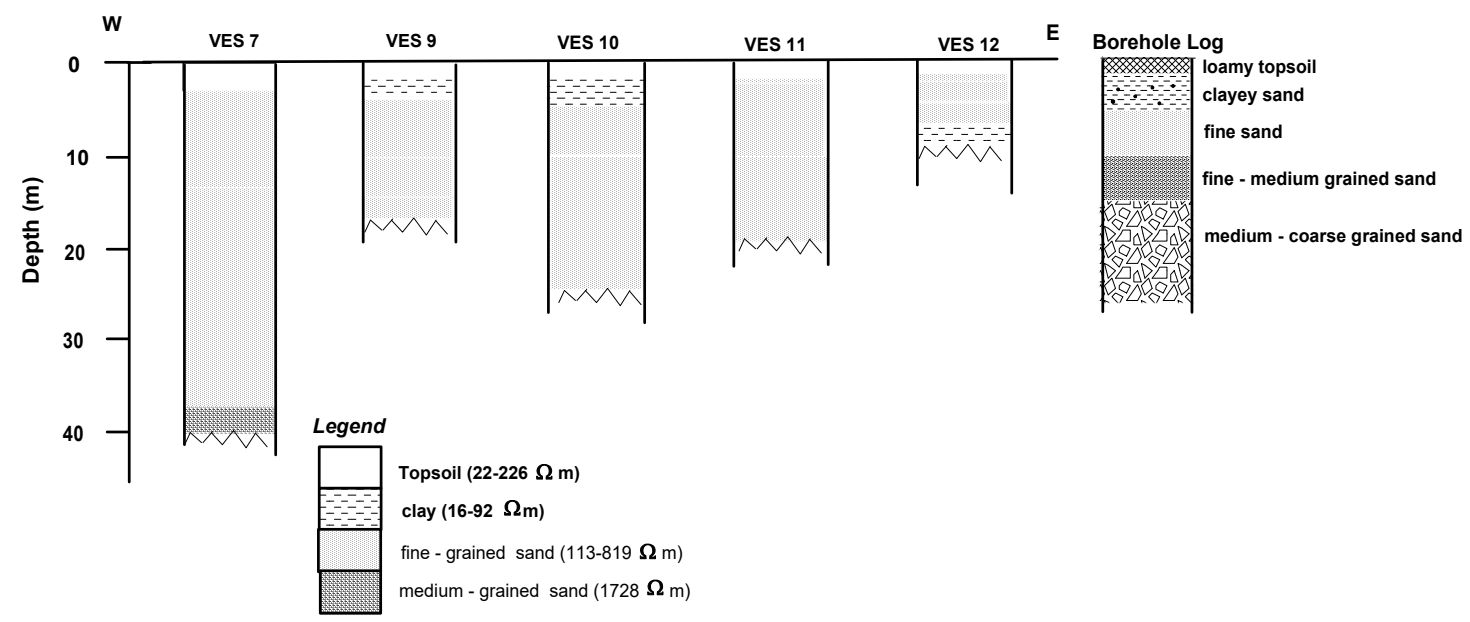

Figure 5. Geoelectric section showing the VES point along the direction west-east.

Table 1. Geoelectrical model of the study area.

\begin{tabular}{ccc}
\hline Nature of Sediment & Lithology (Inferred) & Resistivity $\mathbf{( \Omega m})$ \\
\hline Unsaturated sediment & Top soil & $21 \leq \rho \leq 226$ \\
\hline \multirow{2}{*}{ Saturated sediments } & Clay & $16 \leq \rho \leq 92$ \\
& Clayey sand & $95 \leq \rho \leq 113$ \\
& Fine-grained sand & $113 \leq \rho \leq 819$ \\
& Medium-grained sand & $1086 \leq \rho \leq 1728$ \\
\hline & Coarse sand & 4205 \\
\hline
\end{tabular}

\subsection{Aquifer Protective Capacity}

The hydrogeological characteristics of a site useful in the simulation of groundwater flow and in evaluating overburden protective capacity and transmissivity of an area are the Dar-Zarrouk parameters (i.e., longitudinal conductance $S_{L}$, and transverse resistance $R$ ) [22].

The longitudinal conductance $S_{L}$, which is regarded as the medium's ability to retard and filter percolating fluid is considered as the protective capacity of the overburden and expressed as,

$$
S_{L}=h / \rho=\sum_{i=1}^{n}\left(\frac{h_{i}}{\rho_{i}}\right)=\frac{h_{1}}{\rho_{1}}+\frac{h_{2}}{\rho_{2}}+\frac{h_{3}}{\rho_{3}}+---+\frac{h_{n}}{\rho_{n}}
$$

It can also be expressed as

$$
S_{L}=\sigma_{i} h
$$

where $\sigma_{\mathrm{i}}$ is the layer conductivity analogous to the layer transmissivity $T$,

$$
T=K h=K \frac{S_{L}}{\sigma}
$$

The total transverse resistance $R$ is given by,

$$
R=h \cdot \rho=\sum_{i=1}^{n}\left(h_{i} \rho_{i}\right)=h_{1} \rho_{1}+h_{2} \rho_{2}+h_{3} \rho_{3}+---+h_{n} \rho_{n}
$$

The derived longitudinal conductance values in Table 2, calculated from obtained resistivity and thicknesses using Equation (1) for various layers at different VES stations were used to produce a protective capacity map (Figure 6).The overburden protective capacity was evaluated based on the 
rating approach by [23], and modified by [24] and is given as $>1$ (excellent), $0.5-1$ (very good), 0.1-0.49 (good), 0.06-0.09 (moderate), 0.01-0.05 (weak) and $<0.01$ (poor).

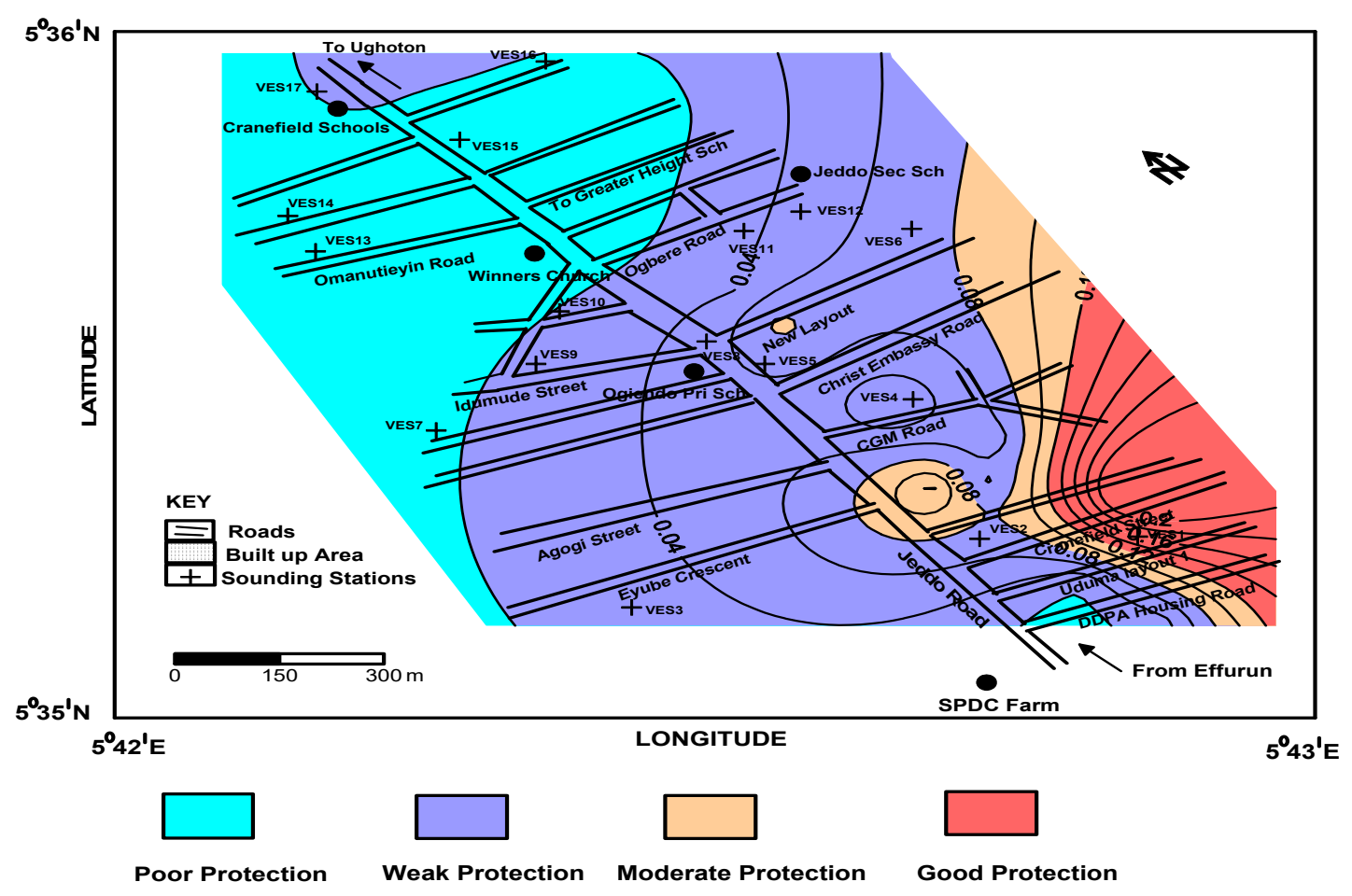

Figure 6. Map of aquifer protective capacity.

From the analysis of Table 2, about $17.7 \%$ of the surveyed area in the eastern flank has good protective capacity and this coincides with zones of appreciable overburden thickness with clayey columns thick enough to protect the aquifer in the area from surface polluting fluid. In total, $17.7 \%$ in the eastern flank of Jeddo has moderate capacity, while 52.9\% located in the central flank falls within areas of weak protective capacity and this is because of the presence of underlying layers of clayey sand. In the study area in the western region, $11.7 \%$ has poor protective capacity because of low porosity of the rock present in the layers which allows the aquifer to be prone to contamination resulting from short residence time in the sandy layers [25]. Figure 6 clearly shows this distribution pattern of the aquifer protective capacity. 
Table 2. Aquifer characteristics of the VES station in the study area.

\begin{tabular}{|c|c|c|c|c|c|c|c|c|c|c|c|c|c|}
\hline $\begin{array}{c}\text { VES } \\
\text { STATION }\end{array}$ & Latitude & Longitude & $\begin{array}{c}\text { Elevation } \\
(\mathrm{m})\end{array}$ & $\begin{array}{c}\text { Aquifer } \\
\text { Resistivity } \\
(\Omega \mathrm{m})\end{array}$ & $\begin{array}{l}\text { Depth to } \\
\text { Aquifer } \\
\text { (m) }\end{array}$ & $\begin{array}{l}\text { Aquifer } \\
\text { Thickness } \\
\text { (m) }\end{array}$ & $\begin{array}{c}\text { Longitudinal } \\
\text { Conductance } \\
\left(\Omega^{-1}\right)\end{array}$ & $\begin{array}{c}\text { Transverse } \\
\text { Resistance } \\
\left(\Omega \mathrm{m}^{2}\right)\end{array}$ & $\begin{array}{c}\text { Conductivity, } \\
\sigma\left(\Omega^{-1}\right)\end{array}$ & $K \sigma$ & $\begin{array}{l}\text { Transmissivity, } \\
\left(\mathrm{m}^{2} \text { day }^{-1}\right)\end{array}$ & $\begin{array}{l}\text { Static Water } \\
\text { Level }\end{array}$ & $\begin{array}{c}\text { Aquifer } \\
\text { Protective } \\
\text { Capacity } \\
\text { (Longitudina } \\
\text { Conductance) }\end{array}$ \\
\hline 1 & 5.5881 & 5.7120 & 6.0 & 392 & 31.4 & 2.30 & 0.127 & 913 & 0.002550 & 0.0676 & 61.7 & 3.12 & Good \\
\hline 2 & 5.5882 & 5.7104 & 6.3 & 402 & 2.5 & 5.80 & 0.035 & 2321 & 0.002490 & 0.0600 & 139.3 & 4.14 & Weak \\
\hline 3 & 5.5890 & 5.7092 & 7.7 & 283 & 4.8 & 22.01 & 0.024 & 6231 & 0.003530 & 0.0865 & 334.0 & 5.49 & Weak \\
\hline 4 & 5.5908 & 5.7099 & 8.1 & 1112 & 29.8 & 4.14 & 0.261 & 4603 & 0.000899 & 0.0258 & 188.8 & 5.59 & Good \\
\hline 5 & 5.5910 & 5.7078 & 12.7 & 1185 & 8.3 & 5.70 & 0.057 & 6760 & 0.000844 & 0.0189 & 127.8 & 9.55 & Moderate \\
\hline 6 & 5.5919 & 5.7080 & 5.3 & 1683 & 21.2 & 2.40 & 0.053 & 3970 & 0.000594 & 0.0178 & 70.7 & 2.06 & Moderate \\
\hline 7 & 5.5909 & 5.7070 & 6.4 & 1728 & 37.5 & 6.80 & 0.126 & 11,732 & 0.000579 & 0.0166 & 194.8 & 3.88 & Good \\
\hline 8 & 5.5925 & 5.7064 & 8.2 & 1397 & 3.6 & 3.30 & 0.020 & 4560 & 0.000716 & 0.0168 & 76.6 & 5.32 & Weak \\
\hline 9 & 5.5942 & 5.7048 & 3.5 & 161 & 11.6 & 9.70 & 0.086 & 1567 & 0.006210 & 0.1645 & 257.8 & 1.40 & Moderate \\
\hline 10 & 5.5950 & 5.7041 & 8.0 & 501 & 6.5 & 4.50 & 0.035 & 2270 & 0.001990 & 0.0545 & 123.7 & 5.10 & Weak \\
\hline 11 & 5.5985 & 5.7031 & 8.6 & 517 & 11.9 & 10.50 & 0.015 & 5451 & 0.001930 & 0.0561 & 305.8 & 5.50 & Weak \\
\hline 12 & 5.5994 & 5.7029 & 8.9 & 818 & 2.5 & 2.10 & 0.018 & 1729 & 0.001220 & 0.0366 & 63.3 & 5.70 & Weak \\
\hline 13 & 5.5964 & 5.7016 & 4.6 & 995 & 12.8 & 6.10 & 0.008 & 6059 & 0.001000 & 0.0228 & 138.1 & 2.50 & Poor \\
\hline 14 & 5.5974 & 5.7001 & 4.7 & 662 & 9.8 & 38.50 & 0.017 & 25,483 & 0.001510 & 0.0386 & 138.1 & 2.40 & Weak \\
\hline 15 & 5.5984 & 5.6996 & 9.0 & 1379 & 11.3 & 75.90 & 0.010 & 104,674 & 0.000135 & 0.0033 & 245.2 & 5.60 & Weak \\
\hline 16 & 5.5994 & 5.6989 & 9.9 & 1086 & 8.3 & 5.30 & 0.036 & 5810 & 0.000921 & 0.0225 & 130.7 & 6.00 & Weak \\
\hline 17 & 5.5997 & 5.6967 & 3.4 & 1038 & 1.5 & 53.80 & 0.006 & 55,907 & 0.000182 & 0.0049 & 276.7 & 1.40 & Poor \\
\hline
\end{tabular}




\subsection{Aquifer Transmissivity}

Aquifer transmissivity was determined using the analytical relationship between hydraulic conductivity $(K)$ and thickness of the aquifer $h$, given in Equation (3). The hydraulic conductivity of sandy layers in Warri environs reported to range between $24.19 \mathrm{~m} /$ day and $30.24 \mathrm{~m} /$ day [26] was assumed for calculating the transmissivity of the aquifer. The aquifer transmissivity rating according to the standards of Gheorghe (1978) as shown in Table 3 was used in this study. The values of transmissivity obtained for the aquifers within the study area are $T_{\text {mean }}=169 \mathrm{~m}^{2} \mathrm{day}^{-1}, T_{\min }=61.7 \mathrm{~m}^{2}$ day $^{-1}, T_{\max }=334 \mathrm{~m}^{2}$ day $^{-1}$ (Table 2). The highest value of $T$ obtained is for VES 3 with $334 \mathrm{~m}^{2} /$ day. Figure 7 presents the map of aquifer transmissivity.

Table 3. Gheorghe standard for transmissivity $(T)$ [27].

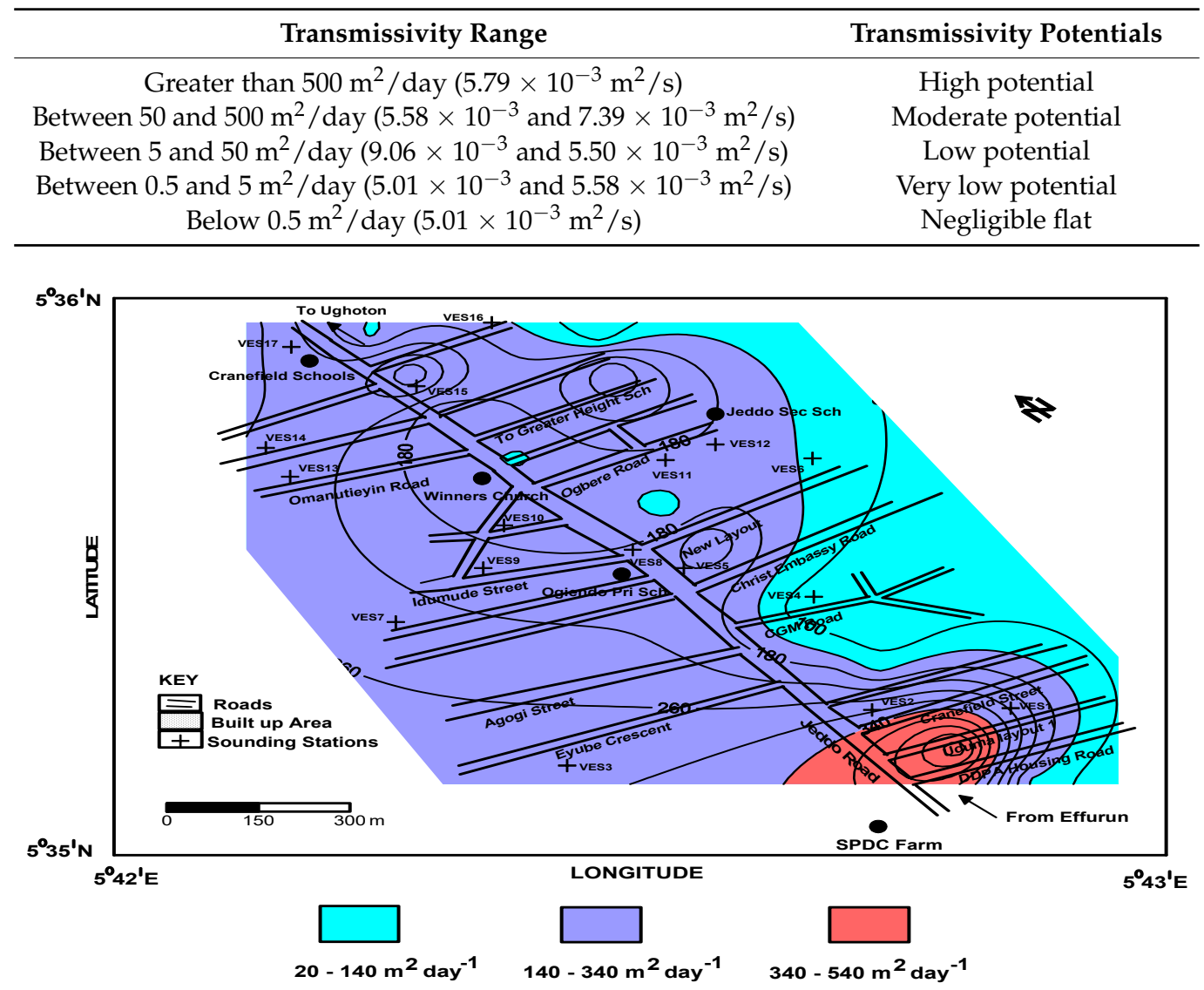

Figure 7. Map of aquifer transmissivity.

The map of aquifer resistivity is shown in Figure 8. The low values of resistivity of the aquifers ranging between 161 and $1728 \Omega \mathrm{m}$ indicate the soil type of the aquifer and/or that the aquifer itself might be contaminated since relative high resistivity value imply a low concentration of conducting materials and thus of high ground water quality [28]. Figure 9 shows the map of depth to the aquifer. The depth to the water table tends to be highest around VES 7 with a value of $37.5 \mathrm{~m}$ and lowest at VES 17 with $1.5 \mathrm{~m}$. The mean depth to aquifer in Jeddo is $12.7 \mathrm{~m}$. The aquifer thickness also varies from $2.1 \mathrm{~m}$ to $75.9 \mathrm{~m}$ with a mean thickness of $15 \mathrm{~m}$. The contour map of the diagnostic factor (Figure 10), gives a detailed distribution pattern of the ratio of the transmissivity to transverse resistance, $K \sigma$, and show low values ranging from 0.0033 to 0.1645 , indicating the Benin formation and that the water is not brackish or saline [12,29].

Groundwater level measurement, relative geographic position of the wells, and elevation were taken and used to obtain the static water level in the area to determine the direction of flow of the 
aquifer. The static water level $\left(\mathrm{S}_{\mathrm{WL}}\right)$ of the area was calculated by subtracting the depth to the water level from earth surface, $D_{W L}$, from the elevation with respect to the mean sea level (E), in the hand-dug wells [30]. This is given by the equation $S_{W L}=E-D_{W L}$. This coincides with the true water level in the case of unconfined aquifer. Generally, depths to water are deeper in areas with high elevations and vice-versa. Thus, depths to water typically is greater beneath hills than valleys but sometimes there are exceptions as observed in this study, resulting from influence on the water table due to some man-made activities such as overlying soil and rock removed leading to shallow depths to water [31].

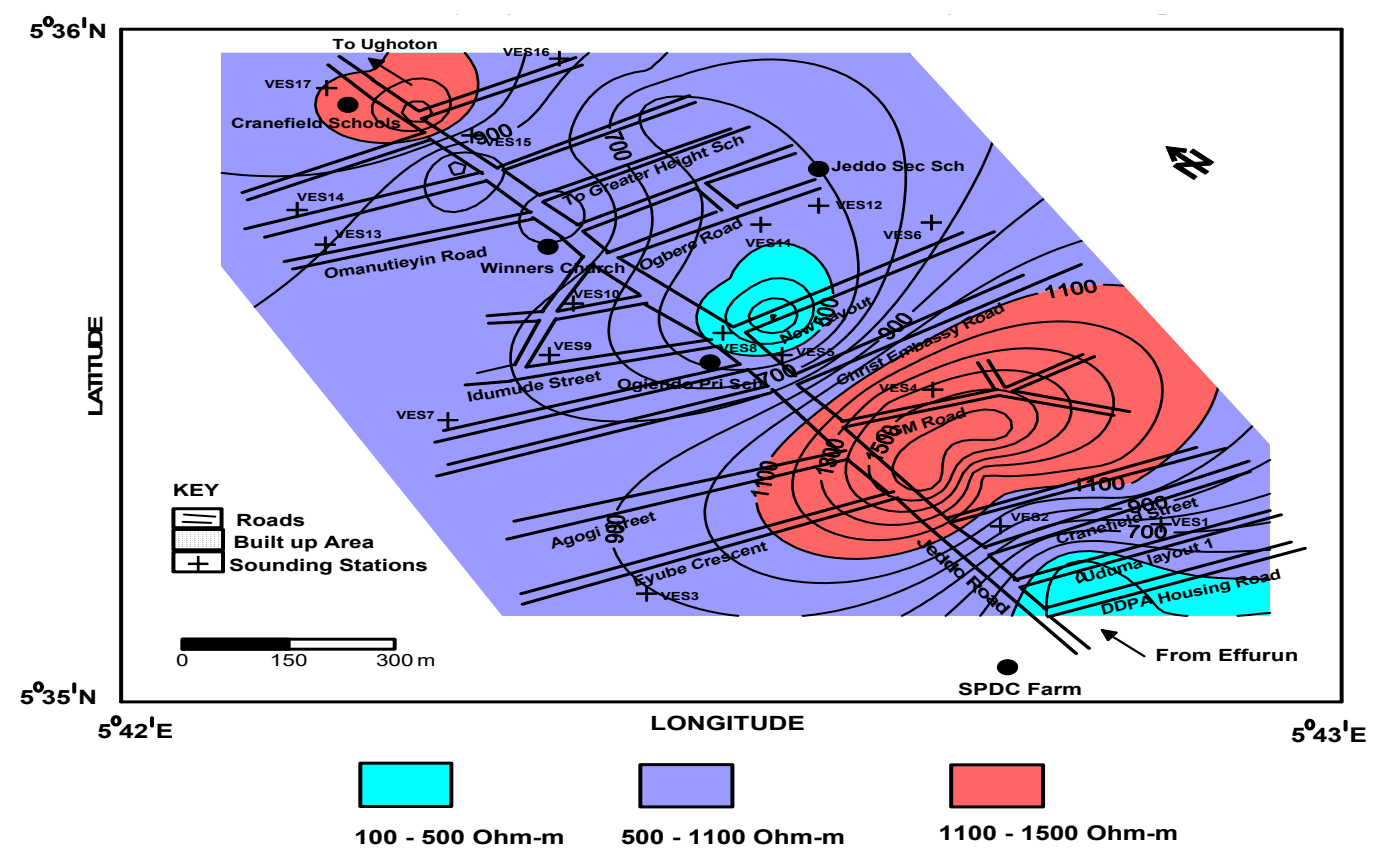

Figure 8. Map of aquifer resistivity.

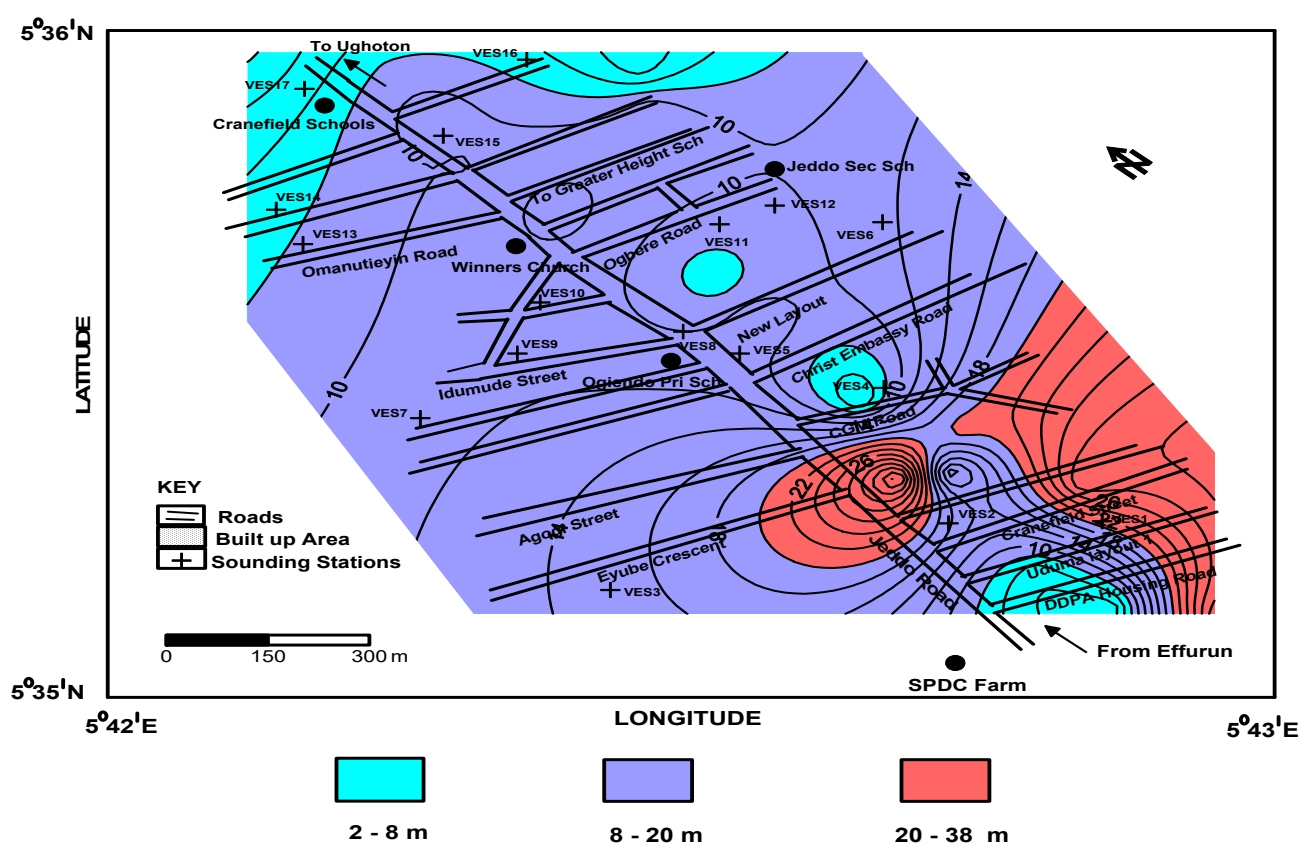

Figure 9. Map of depth to the aquifer. 


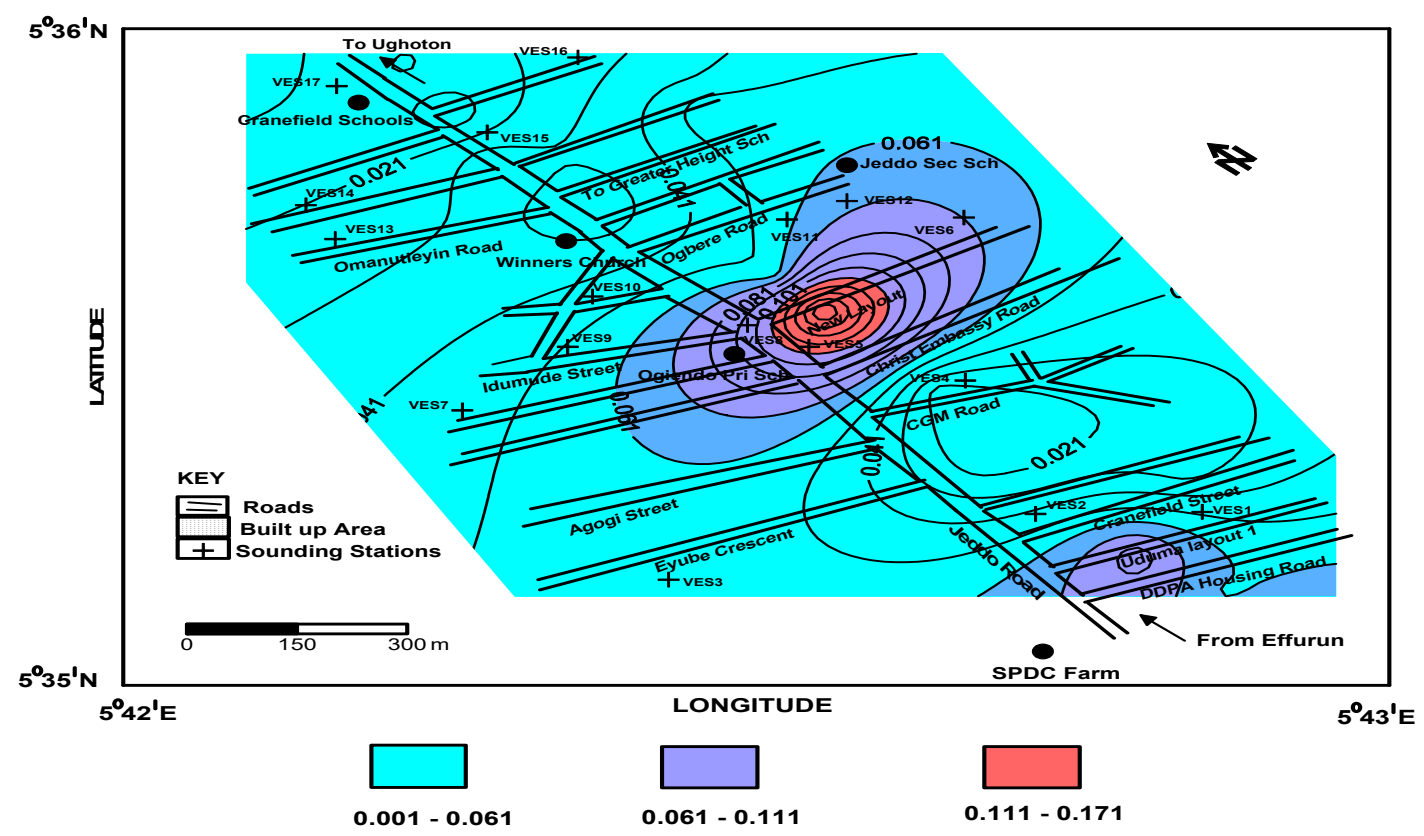

Figure 10. Map of the diagnostic factor.

The contour map of static water level (Figure 11) shows that the flow is towards river Ughoton in the northeast-southwest direction. Locally, variations as to this flow can be observed. These variations occur because of directional changes of groundwater flow, associated with the occurrence of a possible clay layer.

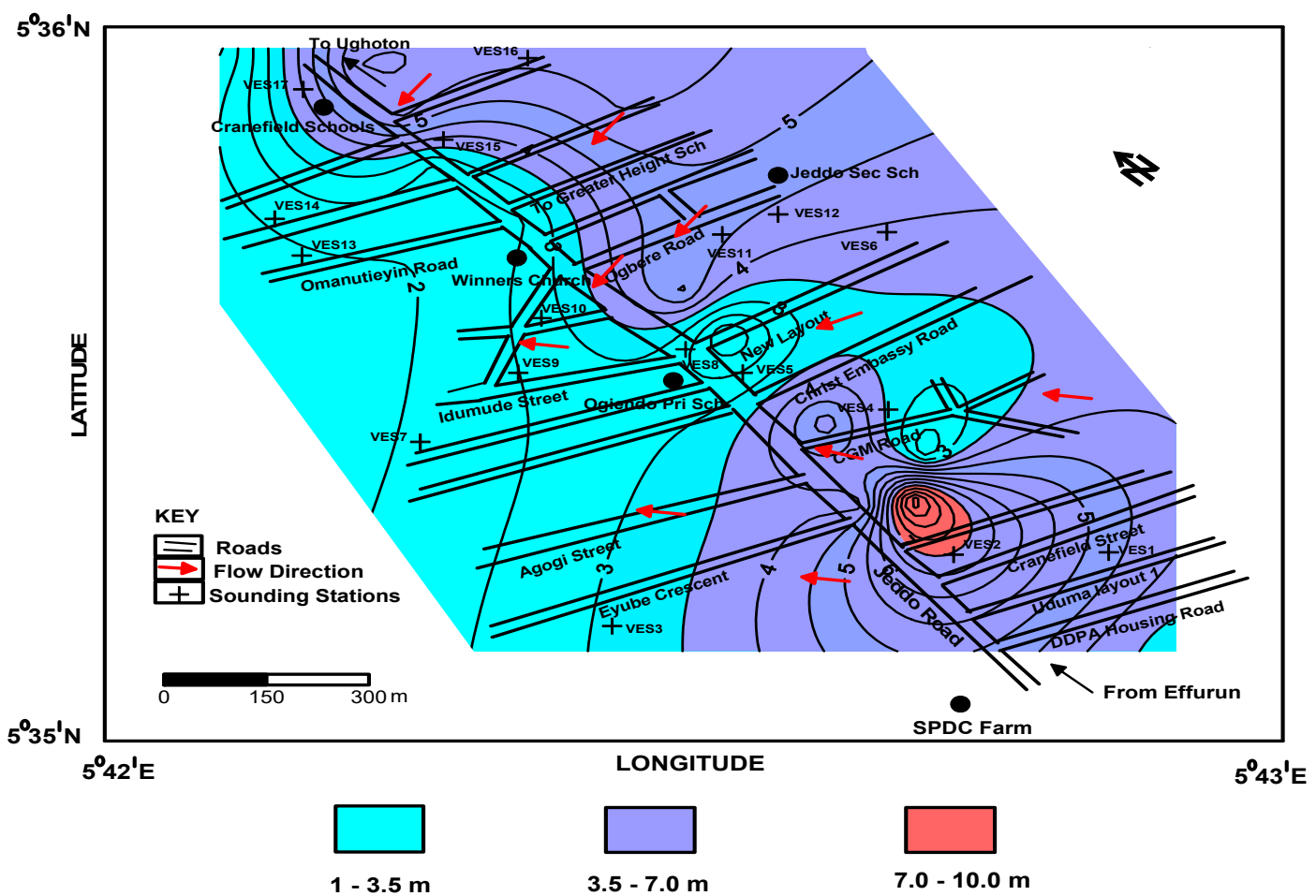

Figure 11. Map of static water level showing direction of flow. 


\subsection{Hydrogeochemical Analysis}

Hydrogeochemical analysis was carried out on water samples collected from four hand-dug wells and eight boreholes in the study area using Grab sampling method in other to obtain the water quality index $(W Q I)$. Twenty-one parameters were chosen for the calculation of $W Q I$ which was done by employing the weighted arithmetic index method and comparing the results with the recommended standard of drinking water by World Health Organization (WHO) and Nigerian Federal Environmental Protection Agency (FEPA). The calculation of the quality rating scale for each parameter was done by using the equation:

$$
Q_{i}=\frac{C_{i}}{S_{i}} \times 100
$$

where $Q_{i}$ is the quality rating scale, $C_{i}$ is the concentration of each parameter, and $S_{i}$ is the recommended standard of each parameter. The inverse of the recommended standard gave the relative weight $\left(W_{i}\right)$ proportional to the recommended standard $\left(S_{i}\right)$ of the corresponding parameter. The overall water quality index is given by Equation (6) and Table 4 the water quality index rating.

$$
W Q I=\frac{\sum Q_{i} W_{i}}{\sum W_{i}}
$$

The results of the hydrogeochemical analysis are shown in Tables 5 and 6 . Most of the values of the parameters obtained falls within the permissible limit of WHO and FEPA except for the high lead content in some of the hand-dug wells and a slightly acidic water of 6.0. For borehole water, there is a slightly high $\mathrm{pH}$ value of 5. For the hand-dug well, the calculated WQI is 199.2 and the WQI for borehole is 194.3. Comparing these values with the standard quality classification scheme, the water is poor for both the hand dug well and the borehole. The implication of this is that the water will require some level of purification before it is made available to the people as potable water.

Table 4. Water quality index classification [32].

\begin{tabular}{cc}
\hline Water Quality Index Level & Water Quality Status \\
\hline$<50$ & Excellent \\
$50-100$ & Good \\
$100-200$ & Poor \\
$200-300$ & Very poor \\
$>300$ & Unsuitable for drinking \\
\hline
\end{tabular}


Table 5. Statistical summary of the hydro geochemical analysis for hand-dug wells in the study area. WHO: World Health Organization;FEPA: Federal Environmental Protection Agency.

\begin{tabular}{|c|c|c|c|c|c|c|c|c|c|c|}
\hline \multirow{2}{*}{ Parameters (mg/L) } & \multicolumn{2}{|c|}{ Standard Values $\left(S_{i}\right)$} & \multicolumn{3}{|c|}{ Observed Values } & \multirow[t]{2}{*}{$\begin{array}{c}\text { Standard } \\
\text { Deviation }\end{array}$} & \multirow[t]{2}{*}{ Variance } & \multirow[t]{2}{*}{$\begin{array}{c}\text { Quality } \\
\text { Rating }\left(Q_{i}\right)\end{array}$} & \multirow[t]{2}{*}{$\begin{array}{l}\text { Unit Weight } \\
\left(W_{i}\right)\end{array}$} & \multirow[t]{2}{*}{$Q_{i} W_{i}$} \\
\hline & WHO & FEPA & Min & $\operatorname{Max}$ & Mean & & & & & \\
\hline Temperature $\left({ }^{\circ} \mathrm{C}\right)$ & 35 & 27 & 28.00 & 28.20 & 28.10 & 0.100 & 0.1000 & 80.30 & 0.030 & 2.410 \\
\hline TSS & 10 & 10 & 0.04 & 0.93 & 0.50 & 0.300 & 0.1000 & 5.00 & 0.100 & 0.500 \\
\hline TDS & 500 & 500 & 0.83 & 18.66 & 8.00 & 7.900 & 62.1000 & 1.60 & 0.002 & 0.003 \\
\hline Alkalinity & 250 & 250 & 0.13 & 2.93 & 1.50 & 1.000 & 1.0000 & 0.60 & 0.004 & 0.002 \\
\hline Total hardness & 200 & 150 & 2.45 & 3.10 & 3.00 & 0.300 & 0.1000 & 1.55 & 0.005 & 0.008 \\
\hline Color & 15 & 15 & 11.00 & 21.00 & 16.00 & 3.800 & 14.5000 & 106.70 & 0.067 & 7.149 \\
\hline Carbonate & 51 & 50 & 23.16 & 61.73 & 49.20 & 15.200 & 230.7000 & 80.70 & 0.200 & 16.140 \\
\hline Chloride & 250 & 250 & 0.15 & 0.74 & 0.40 & 0.300 & 0.1000 & 0.16 & 0.004 & 0.010 \\
\hline Nitrate & 50 & 50 & 1.98 & 2.04 & 2.00 & 0.002 & 0.0006 & 1000 & 0.020 & 200 \\
\hline Sulfate & 100 & 500 & 0.08 & 0.34 & 0.20 & 1.500 & 2.4000 & 0.20 & 0.010 & 0.002 \\
\hline Lead & 0.01 & 0.01 & 0.01 & 0.04 & 0.02 & 0.001 & 0.0002 & 200 & 100 & 20,000 \\
\hline Potassium & 100 & 100 & 1.24 & 2.38 & 1.70 & 0.700 & 0.5000 & 1.70 & 0.010 & 0.017 \\
\hline Sodium & 200 & 200 & 0.04 & 0.08 & 0.08 & 0.003 & 0.0010 & 0.04 & 0.005 & 0.002 \\
\hline Phosphate & 5 & 5 & 0.21 & 0.59 & 0.50 & 0.010 & 0.2000 & 10.00 & 0.200 & 2.000 \\
\hline Calcium & 200 & 200 & 101.84 & 124.10 & 117.20 & 9.000 & 81.0000 & 58.60 & 0.005 & 0.293 \\
\hline Magnesium & 150 & 100 & 10.84 & 9.46 & 10.90 & 1.100 & 1.1400 & 7.30 & 0.007 & 0.051 \\
\hline Copper & 2 & 1 & 0.87 & 0.09 & 0.30 & 0.300 & 0.1000 & 1.50 & 0.500 & 7.500 \\
\hline Iron & 0.30 & 0.30 & 0.20 & 0.40 & 0.30 & 0.095 & 0.0120 & 100 & 0.300 & 30.000 \\
\hline Turbidity & 5 & 1 & 1.90 & 1.29 & 1.63 & 0.220 & 0.0670 & 32.60 & 0.200 & 6.520 \\
\hline $\mathrm{pH}$ & $6.50-8.50$ & $6-9$ & 5.30 & 6.40 & 6.00 & 0.100 & 0.7000 & 92.30 & 0.010 & 0.923 \\
\hline Counts $(\mathrm{cfu} / \mathrm{mL})$ & 10 & 10 & 2.08 & 2.64 & 2.30 & 0.800 & 0.1000 & 23.00 & 0.100 & 2.300 \\
\hline Conductivity $(\mu \mathrm{s} / \mathrm{cm})$ & 1000 & 1000 & 92.10 & 93.10 & 92.80 & 0.400 & 0.2 & 0.04 & 0.001 & 0.00004 \\
\hline & & & & & & & & & $\sum W_{i}=101.78$ & $\sum Q_{i} W_{i}=20,275.83$ \\
\hline
\end{tabular}


Table 6. Statistical summary of the hydrogeochemical analysis for boreholes in the study area.

\begin{tabular}{|c|c|c|c|c|c|c|c|c|c|c|}
\hline \multirow{2}{*}{ Parameters (mg/L) } & \multicolumn{2}{|c|}{ Standard Values $\left(S_{i}\right)$} & \multicolumn{3}{|c|}{ Observed Values } & \multirow[t]{2}{*}{$\begin{array}{c}\text { Standard } \\
\text { Deviation } \\
\end{array}$} & \multirow[t]{2}{*}{ Variance } & \multirow[t]{2}{*}{$\begin{array}{c}\text { Quality } \\
\text { Rating }\left(Q_{i}\right)\end{array}$} & \multirow[t]{2}{*}{$\begin{array}{c}\text { Unit Weight } \\
\left(W_{i}\right)\end{array}$} & \multirow[t]{2}{*}{$Q_{i} W_{i}$} \\
\hline & WHO & FEPA & Min & $\operatorname{Max}$ & Mean & & & & & \\
\hline Temperature $\left({ }^{\circ} \mathrm{C}\right)$ & 35 & 27 & 28.00 & 28.40 & 28.100 & 0.10 & 0.0200 & 80.30 & 0.030 & 2.4090 \\
\hline TSS & 10 & 10 & 0.17 & 1.56 & 0.800 & 0.50 & 0.2400 & 8.00 & 0.100 & 0.8000 \\
\hline TDS & 500 & 500 & 3.38 & 22.17 & 13.800 & 7.20 & 5.2000 & 2.76 & 0.002 & 0.0060 \\
\hline Alkalinity & 250 & 250 & 0.53 & 4.92 & 2.500 & 1.60 & 2.5000 & 1.00 & 0.004 & 0.0040 \\
\hline Hardness & 200 & 150 & 3.02 & 3.21 & 3.100 & 0.07 & 0.0050 & 1.55 & 0.005 & 0.0080 \\
\hline Color & 15 & 15 & 4.00 & 20.00 & 11.500 & 5.50 & 30.0000 & 76.70 & 0.067 & 5.1400 \\
\hline Carbonate & 51 & 50 & 10.46 & 59.14 & 33.400 & 19.60 & 385.9000 & 58.00 & 0.020 & 1.1600 \\
\hline Chloride & 250 & 250 & 0.09 & 0.53 & 0.300 & 0.20 & 0.0600 & 0.12 & 0.004 & 0.0050 \\
\hline Nitrate & 50 & 50 & 1.93 & 2.00 & 2.000 & 0.03 & 0.0010 & 4.00 & 0.020 & 0.0800 \\
\hline Sulfate & 100 & 500 & 0.01 & 0.16 & 0.100 & 0.07 & 0.0050 & 0.10 & 0.001 & 0.0030 \\
\hline Lead & 0.01 & 0.01 & 0.01 & 0.02 & 0.002 & 0.01 & 0.0001 & 200.00 & 100.000 & 20,000 \\
\hline Potassium & 100 & 100 & 1.48 & 2.84 & 2.000 & 0.40 & 0.2000 & 2.00 & 0.001 & 0.0020 \\
\hline Sodium & 200 & 200 & 0.04 & 1.34 & 0.600 & 0.50 & 0.2600 & 0.30 & 0.050 & 0.1500 \\
\hline Phosphate & 5 & 5 & 0.51 & 0.69 & 0.630 & 0.06 & 0.0040 & 1.26 & 2.000 & 0.2500 \\
\hline Calcium & 200 & 200 & 119.30 & 128.43 & 123.000 & 4.40 & 19.800 & 61.50 & 0.005 & 3.1000 \\
\hline Magnesium & 150 & 100 & 9.73 & 10.43 & 10.100 & 0.30 & 0.1000 & 6.73 & 0.070 & 0.4700 \\
\hline Copper & 2.00 & 1.00 & 0.09 & 0.10 & 0.100 & 0.01 & 0.0001 & 5.00 & 0.500 & 2.5000 \\
\hline Iron & 0.30 & 0.3 & 0.02 & 0.04 & 0.050 & 0.02 & 0.0003 & 166.70 & 0.200 & 33.3400 \\
\hline Turbidity & 5 & 1 & 0.11 & 0.96 & 0.640 & 0.27 & 0.0730 & 128.00 & 0.300 & 38.4000 \\
\hline $\mathrm{pH}$ & $6.5-8.5$ & $6-9$ & 4.10 & 6.60 & 5.000 & 0.90 & 0.8000 & 73.52 & 0.010 & 22.1000 \\
\hline Coliform counts $(\mathrm{cfu} / \mathrm{mL})$ & 10 & 10 & 0.38 & 7.00 & 2.000 & 2.20 & 4.9000 & 20.00 & 0.100 & 2.0000 \\
\hline Conductivity $(\mu \mathrm{s} / \mathrm{cm})$ & 1000 & 1000 & 93.50 & 92.30 & 9.3 & 1.40 & 2.0000 & 0.93 & 0.001 & 0.0009 \\
\hline & & & & & & & & & $\sum W_{i}=103.49$ & $\sum Q_{i} W_{i}=20,111.93$ \\
\hline \multicolumn{11}{|c|}{ WaterQualityIndex $=\frac{\sum Q_{i} W_{i}}{\sum W_{i}}=194.30$} \\
\hline
\end{tabular}




\section{Conclusions}

The lithological identification and the characterization of the conditions of the underground water was made possible from the geophysical survey of the studied area. The geoelectric survey indicates that the area has topsoil, clay, clayey sand, and fine- to coarse-grained sand with various thicknesses and at various depths. These primary parameters were used to determine the Dar-Zarrouk parameters and the electrical conductivity. The longitudinal conductance map shows that the impermeability of the confining clay layer is about $17.6 \%$ of the surveyed area, indicating the area where the aquifer would be protected. The aquifer transmissivity map shows that the transmissivity of the area is of moderate potential with a mean value $T_{\text {mean }}=169 \mathrm{~m}^{2}$ day $^{-1}$ while its maximum value is $T_{\max }=334 \mathrm{~m}^{2}$ day $^{-1}$. The lower values of the diagnostic factor, $k \sigma$, ranging from 0.0033 to 0.1645 , in the map show that the water is not brackish or not saline. Also, the aquifer thickness varies between $2.1 \mathrm{~m}$ at VES 12 and $75.9 \mathrm{~m}$ at VES 15 with an average value of $15 \mathrm{~m}$. The hydrogeochemical analysis of water samples carried out showed values that fall within the permissible limit of WHO and FEPA except for lead, color and $\mathrm{pH}$ values which exceeded the permissible limit. The water from hand-dug wells is of poor quality compared to the water from boreholes. The estimation of elevation from geophysical survey has led to the determination of the pattern and direction of flow of the groundwater as shown in the generated static water table map. Generally, the underground water flow is towards the river Ughoton in the NE-SW direction.Locally, variations as to this flow can be observed. These variations occur because of directional changes of groundwater flow, associated with the occurrence of a possible clay layer.

Acknowledgments: The manuscript has benefitted from reviewers comments with appreciation.

Author Contributions: R.I.-E. and M.O.O. conceived and design the research. M.B. led the geophysical data acquisition. M.O.O., R.I.-E. and O.A. did the data processing and analysis and numerical statistics. M.O.O. and R.I.-E. did the write up.

Conflicts of Interest: The authors declare no conflict of interest.

\section{References}

1. Akpoborie, I.A.; Uriri, A.E.; Efobo, O. Ground water conditions and spatial distribution of lead and cadmium in the shallow aquifer at Effurun-Warri metropolis, Nigeria. Environ. Pollut. 2014, 3, 27-37. [CrossRef]

2. Adejuwon, O.A. Rainfall seasonality in the Niger delta belt, Nigeria. J. Geogr. Reg. Plan. 2012, 5, 51-60.

3. Ward, S.H. Resistivity and induced polarization methods. Geophysics 1990, 1, 147-189.

4. William, L. Fundamentals of Geophysics; Cambridge University Press: Cambridge, UK, 1997.

5. Niwas, S.W.; Singhai, D.C. Estimation of aquifer transmissivity from Dar-Zarrouk parameters in porous media. J. Hydrol. 1981, 50, 393-399. [CrossRef]

6. Aristedemou, E.; Thomas-Betts, A. DC Resistivity and induced polarization investigations at a waste disposal site and its environments. J. Appl. Geophys. 2000, 44, 275-302. [CrossRef]

7. Hubbard, S.S.; Rubin, Y. Hydrogeophysics; Springer: Dordrecht, The Netherlands, 2005; Volume 50, p. 523.

8. Butler, J.J., Jr. Hydrogeological Methods for Estimation of Spatial Variations in Hydraulic Conductivity; Springer: Dordrecht, The Netherlands, 2005; pp. 23-58.

9. Karlik, G.; Kaya, A.M. Investigation of groundwater contamination using electric and electromagnetic methods at an open Waste-Disposal site: A case study from Isparta, Turkey. Environ. Geol. 2001, 40, 725-731. [CrossRef]

10. Anomohanran, O. Determination of groundwater in Asaba, Delta State, Nigeria. Int. J. Phys. Sci. 2011, 6, 7651-7659.

11. Jegede, S.I.; Ujuanbi, O.; Abdullahi, N.K.; Iserhien-Emekeme, R.E. Mapping and monitoring of leachate plume migration at an open waste disposal site using Non-Invasive methods. Res. J. Environ. Earth Sci. 2012, 4, 26-33.

12. Udoinyang, I.E.; Igboekwu, M.U. A quifer transmissivity, Dar-Zarroukparameters and the direction of flow of suspended particulate matter in boreholes in MOUAU and the Kwa Ibo river, Umudike-Nigeria. Greener J. Phys. Sci. 2012, 2, 70-84. 
13. Imali, H.; Dharmagunwardhane, H.A. Use of Resistivity Sounding Results for Estimating Transmissivity of Aquifers: A Case Study from North Central Province, Sri Lanka. In Proceedings of the 29th Technical Sessions of Geophysical Society of Sri Lanka, Jinadasa Katupotha, 22 February 2013; pp. 21-23.

14. Iserhien-Emekeme, R.E. Electrical resistivity survey for predicting aquifer at Onicha-Ugbo, Delta State, Nigeria. J. Appl. Math. Phys. 2014, 2, 520-527. [CrossRef]

15. Anomohanran, O.; Iserhien-Emekeme, R.E. Estimation of aquifer parameters in Erho, Nigeria using the Cooper-Jacob evaluation method. Am. J. Environ. Sci. 2014, 10, 500-508. [CrossRef]

16. Ofomola, M.O. Mapping of aquifer contamination using Geoelectric methods at a municipal solid waste disposal site in Warri, Southern Nigeria. J. Appl. Geol. Geophys. 2015, 3, 39-47.

17. Short, K.C.; Stauble, A.J. Outline of the Niger delta. Bull. Am. Assoc. Pet. Geol. 1967, 54, 761-779.

18. Murat, R.C. Stratigraphy and paleogeography of the cretaceous and lower tertiary in Southern Nigeria. In African Geology; University of Ibadan Press: Ibadan, Nigeria, 1970; pp. 635-648.

19. Asseez, O.L. Review of the stratigraphy, sedimentation and structure of the Niger delta. In Geology of Nigeria; Kogbe, C.A., Ed.; Rock View (Nig.) Ltd.: Jos, Nigeria, 1989; pp. 311-324.

20. Nwajide, C.S. A Guide for Geological Field Trips to Anambra and Related Sedimentary Basins in Southeastern Nigeria; Petroleum Development Trust Fund, University of Nigeria, Nsukka: Nsukka, Nigeria, 2006; p. 68.

21. Tamunosiki, D.; Ming, G.H.; Uko, E.D.; Tamunobereton-ari, I.; Emudianughe, J.E. Porosity modeling of the South-East Niger delta basin, Nigeria. Int. J. Geol. Earth Environ. Sci. 2014, 4, 49-60.

22. Henriet, J.P. Direct applications of the Dar Zarrouk Parameters in groundwater surveys. Geophys. Prospect. 1975, 24, 344-353. [CrossRef]

23. Oladapo, M.I.; Mohammed, M.Z.; Adeoye, O.O.; Adetola, B.A. Geoelectrical investigation of the Ondo State Housing Corporation Estate, IjapoAkure Southwestern Nigeria. J. Min. Geol. 2004, 40, 41-48.

24. Ofomola, M.O. Aquifer Characterization and groundwater quality studies in part of Niger Delta Area using geoelectric and hydrogeochemical methods. Niger. J. Phys. 2014, 25, 96-106.

25. Mundel, J.A.; Lother, L.; Oliver, E.M.; Allen-long, S. Aquifer Vulnerability Analysis for Water Resource Production; Indian Department of Environmental Management: Indianapolis, IN, USA, 2003; Volume 25.

26. Akpoborie, I.A.; Ekakite, O.A.; Adaikpoh, E.O. The quality of groundwater from dug wells in parts of the Western Niger Delta. Knowl. Rev. 2000, 2, 72-75.

27. Gheorghe, A. Processing and Synthesis of Hydrological Data; Abacus Press: Tumbridge Wells, UK, 1978; pp. 122-136.

28. Okiongbo, K.S.; Akpofure, E. Determination of aquifer properties and groundwater vulnerability mapping using geoelectric method in Yenagoa city and its environs in Bayelsa State, South Nigeria. J. Water Resour. Prot. 2012, 4, 354-362. [CrossRef]

29. Uma, K.O. An appraisal of the groundwater resources of the Imo River Basin, Nigeria. J. Min. Geol. 1989, 25, 305-315.

30. Buddermeier, R.W.; Schloss, J.A. Groundwater Storage and Flow. 2000. Available online: http://www.kgs. Ukans.edu/Heightplains / atlas / / apgengw.htm (accessed on 25 March 2017).

31. Fetter, C.W. Applied Hydrology, 3rd ed.; Macmillan College Publishing Company, Inc.: New York, NY, USA, 1994; Volume 114.

32. Amadi, A.N. Assessing the effects of aladimma dumpsite on soil and groundwater using water quality index and factor analysis. Aust. J. Basic Appl. Sci. 2011, 5, 763-770.

(C) 2017 by the authors. Licensee MDPI, Basel, Switzerland. This article is an open access article distributed under the terms and conditions of the Creative Commons Attribution (CC BY) license (http://creativecommons.org/licenses/by/4.0/). 